\title{
Collapse of a reproducing population of non-native African jewelfish (Hemichromis letourneuxi) in a Florida lake
}

\author{
Jeffrey E. Hill \\ I Program of Fisheries and Aquatic Sciences, School of Forest Resources and Conservation, University of Florida, \\ Tropical Aquaculture Laboratory, 1408 24th Street SE, Ruskin, FL 33570, USA \\ Corresponding author: Jeffrey E. Hill (jeffhill@ufl.edu)
}

Academic editor: E. García-Berthou | Received 16November 2015 | Accepted 22February 2016| Published 16March 2016

Citation: Hill JE (2016) Collapse of a reproducing population of non-native African jewelfish (Hemichromis letourneuxi) in a Florida lake. NeoBiota 29: 35-52. doi: 10.3897/neobiota.29.7213

\begin{abstract}
Established populations of non-natives may collapse without a clear causal mechanism. Hypothetically, fluctuations in habitat structural complexity may influence dynamics of invaders and the biotic resistance offered by predators. Herein I report observations of the collapse of a reproducing population of the nonnative African jewelfish (Hemichromis letourneuxi) in a Florida lake concurrent with an unusual low-water period. I test the hypothesis that predation may have played a key role in the collapse using a combination of field surveys of habitat and fish abundance and predator-prey experiments. Habitat complexity was high before and after the low water period but virtually nonexistent during low water. The abundance of African jewelfish and native juvenile bluegill (Lepomis macrochirus) and eastern mosquitofish (Gambusia holbrooki) declined concurrently with decreasing complexity but the native species rebounded when lake levels increased. Large-bodied natives such as largemouth bass (Micropterus salmoides) and adult bluegill showed no pattern of fluctuation related to habitat complexity. African jewelfish survival was 1.6 times greater at high versus low complexity and over 7 times higher versus no complexity in the presence of largemouth bass. Conversely, eastern mosquitofish, a species that exerts strong effects on small-bodied fishes in structurally complex habitats had no effect on African jewelfish survival. Predation effects on susceptible non-natives should be considered as a potential control action. Population collapse is understudied but may provide insights into long-term dynamics of invaders and information useful for management of problematic species.
\end{abstract}

\section{Keywords}

Population collapse, habitat complexity, drought, biotic resistance, predation, invasive, Cichlidae 


\section{Introduction}

Established populations of non-native species may decline or collapse without human intervention (Simberloff and Gibbons 2004). Some populations eventually rebound though others may remain at low levels or decline to extinction. Pathogens, smallpopulation demographics, or stochastic events are frequent explanations for such fluctuations; however, the cause of the decline is unknown in many cases (Simberloff and Gibbons 2004). Boom-and-bust population cycles have been observed with non-native freshwater fishes in Florida, USA. Some declines are related to cold weather events impacting populations of non-natives of tropical origin (Snodgrass 1991, Trexler et al. 2000, Call et al. 2013). Nevertheless, reasons behind other examples are less clear (Loftus and Kushlan 1987, Fury and Morello 1994, Trexler et al. 2000, Shafland et al. 2008). Hypothetically a variety of abiotic and biotic factors might influence patterns of non-native fish abundance. Evaluating causes of observed population decline or collapse may provide insights into long-term dynamics of invaders and useful information for management of problematic species.

Predators, pathogens, or competitors can prevent establishment of non-natives, reduce their range or abundance, or eliminate local populations (Baltz and Moyle 1993, Byers 2002, Harvey et al. 2004). The influence of biotic resistance should vary spatially and temporally depending on changes in habitat features that mediate interactions among resident species and non-natives, potentially resulting in fluctuating abundance or population collapse of non-natives. Habitat structural complexity is an important factor influencing predator-prey dynamics and hence fish community structure (Savino and Stein 1982, MacRae and Jackson 2001). For example, large-bodied predatory fishes such as largemouth bass (Micropterus salmoides Lacepede) limit the use of open waters by small-bodied fishes (Werner and Hall 1988). Conversely, structurally complex habitat such as dense stands of aquatic macrophytes or other habitats that limit access of large-bodied species (e.g., shallows) reduce the effectiveness of predatory fishes and provide predation refuges for vulnerable species (Werner et al. 1983, Gotceitas and Colgan 1989, DeVries 1990). Differential vulnerability in structurally complex versus simple habitats may lead to the common observation of higher abundance of small-bodied fishes in complex habitats (Werner et al. 1978, Barrientos and Allen 2008). Decline in the density or area of structurally complex habitat generally results in reduced abundance of small-bodied fishes (Ware and Gasaway 1976, Bettoli et al. 1993, Colle and Shireman 1994, Sass et al. 2006) and should increase biotic resistance to susceptible invaders.

Little is known about the impact of biotic resistance on non-native freshwater fish abundance in Florida. Predation has been implicated anecdotally in the severe decline of only one reproducing non-native fish in the state, the silver dollar (Metynnis sp.), where elimination of dense stands of the submersed macrophyte Hydrilla verticilata was thought to have facilitated predation by largemouth bass (Shafland et al. 2008). Despite the lack of data on the influence of biotic resistance on field populations of non-native fishes in Florida, experimental evidence shows that predation and aggres- 
sive competition from natives offer resistance against establishment of many smallbodied (<150 mm total length [TL]) non-natives (Hill et al. 2011, Thompson et al. 2012). Such resistance is hypothesized to result in an overall lack of successful smallbodied invaders despite strong introduction pathways (Thompson et al. 2012). Additional investigation into the general importance of biotic resistance as an influence on invasion success is warranted.

Herein I report observations of the collapse of a reproducing population of the non-native African jewelfish (Hemichromis letourneuxi Sauvage) in a lake in west-central Florida concurrent with an unusual low-water period. A proposed mechanism of the collapse is predation facilitated by the loss of structurally complex refuge habitat. A combination of field observations and experiments were used to test this hypothesis. My objectives were to (1) document changes in habitat complexity in the littoral zone, (2) estimate the relative abundance of African jewelfish and select native fishes using visual sampling to document trends associated with changing habitat, and (3) experimentally investigate the hypothesis that predation may play a key role in the population collapse.

\section{Methods}

\section{Study species}

The small-bodied (75-100 mm TL) African jewelfish (Cichlidae) was first introduced near Miami, Florida in the early 1960s (Rivas 1965) with reports from the Tampa Bay region in west-central Florida since 1974 (Courtenay et al. 1974, USGS 2015). The African jewelfish is of increasing interest in fish sampling and environmental DNA monitoring by management agencies (Kline et al. 2013, Diaz-Ferguson et al. 2014, Moyer et al. 2014). Its recent spread in south, southwest, and west-central Florida (Langston et al. 2010), including expansion into environmentally sensitive protected areas (Kline et al. 2013), is of management concern because of potential impacts on native invertebrates and small-bodied fishes by this aggressive predator (Rehage et al. 2014, Schofield et al. 2014).

\section{Study site}

Observations were made from 2003 to 2013 at Lake St. Clair, Hillsborough County, Florida, a 23.5-ha suburban borrow lake within the Bullfrog Creek basin of the Tampa Bay watershed (lake center near $\left.27^{\circ} 46^{\prime} 23^{\prime \prime} \mathrm{N}, 82^{\circ} 21^{\prime} 57^{\prime \prime} \mathrm{W}\right)$. The water was relatively clear, with mean Secchi disk depths of $203 \mathrm{~cm}(\mathrm{n}=3$, SD = 3) in 2012. Substrates in the littoral zone consisted mostly of sand. The littoral zone had emergent vegetation (mostly Hydrocotyle sp. [in 2003 only], Panicum repens, Pontederia cordata, and Sagittaria lancifolia), with submersed vegetation intermixed (mostly Luziola fluitans, 
with small patches of Potamogeton illinoensis) and a few small areas with filamentous algae. Rising water levels occasionally inundated terrestrial vegetation. Most of the lake was deep $(-4-6.5 \mathrm{~m})$ outside the littoral zone with a steep drop-off and little habitat complexity. Soft sediments dominated the open water zone substrate. A water control structure in the north end of the lake maintains pool level and discharges via underground pipe to the Bullfrog Creek basin.

Water levels fluctuated more than $2 \mathrm{~m}$ during the study period. An unusual lowwater period occurred in the lake for six to seven months in 2007 as a result of an extended drought during 2005-2007. Whole-lake visual surveys showed that the water level had dropped below the littoral zone such that almost no aquatic vegetation was submerged. An area of Scirpus sp. $(\sim 100 \mathrm{~m}$ long $\times 4 \mathrm{~m}$ wide $)$ remained inundated in the northwest portion of the lake. Other structures such as docks were completely or nearly above the water level. Shorelines during low water were typically bare sand with a thin margin of shallow water rapidly dropping off into the deepest zone.

\section{Field observations}

Quantitative field observations were done in three 25-m littoral zone transects along the southeastern ( $\mathrm{n}=60$ samples; 2003 to 2012) and southern shoreline (two transects; $\mathrm{n}=41$ samples each; 2005-2012). Sample numbers by year were $2003=2,2004=2$, $2005=16,2006=24,2007=27,2008=14,2009=14,2010=4,2011=8,2012$ $=15$, and $2013=16$. The two southernmost transects included the public access area with the lake's only boat ramp. The transect locations were fixed because of constraints regarding legal property access along the private lake shore. Habitat complexity, number of African jewelfish, abundance of other small fish, specifically juvenile bluegill ( $\mathrm{Le}$ pomis macrochirus Rafinesque) and eastern mosquitofish (Gambusia holbrooki Girard), and abundance of larger fish, specifically adult bluegill (>100 mm TL) and largemouth bass were noted during each sample.

The complexity of aquatic macrophytes or inundated terrestrial vegetation in each transect was estimated using a ranked, categorical scale. Complexity was assigned a score of 0 if absent, 1 if sparse cover ( $<33 \%$ areal coverage), 2 if moderate cover (33$66 \%$ areal coverage), and 3 if dense cover ( $>66 \%$ areal coverage). These data estimate trends in refuge availability during the study.

Visual surveys for fish were made during daylight hours with the aid of polarized sunglasses and high water clarity. These surveys were done by slowly walking along the shoreline during daylight hours. Fish occasionally responded by moving away into vegetation or deeper water, but generally did not overtly react to the observer. Surveys were not conducted during the brief, cold winter periods (usually December through February) or during windy weather.

African jewelfish were counted. Though small-bodied, this species is active and brightly colored which facilitated observations. In practice, counting large numbers of small-bodied native fishes was difficult and inaccurate. Therefore, estimates of juve- 
nile bluegill $(<100 \mathrm{~mm} \mathrm{TL})$ and eastern mosquitofish abundance were made using a ranked, categorical scale. These species were scored according to the number observed, 0 if none were observed, 1 for $1-19,2$ for 20-99, and 3 for $\geq 100$. Estimates of largemouth bass and adult bluegill $(>100 \mathrm{~mm}$ TL) were made using a ranked, categorical scale where 0 was assigned if the species was absent, 1 if $1-5$ individuals were observed, and 2 if more than 5 were observed. Category ranges were chosen based on preliminary observations in the case of small fishes and frequencies observed during the study for larger species. Largemouth bass was the main predatory species in the lake. Bluegill habitat use frequently differs with body size, with juveniles closely associated with structurally complex habitat in the presence of predatory fishes and less vulnerable adults capable of using more open water habitats (Mittelbach 1981, Werner and Hall 1988, Paukert and Willis 2002). The small-bodied eastern mosquitofish is strongly associated with structurally complex habitat, especially in the presence of predators (Chick and McIvor 1997), and seldom occurs in open water habitats (Werner et al. 1978). I expected that juvenile bluegill and eastern mosquitofish would follow a similar pattern to African jewelfish and decline considerably due to a reduction in refuge habitat associated with the drought. Eastern mosquitofish also is a known aggressive competitor and predator of small-bodied fishes and might influence African jewelfish survival (Meffe 1985, Thompson et al. 2012; see also Predation experiments, below).

Whole-lake presence/absence surveys were done for African jewelfish to determine the spatial distribution of the species during the study. These surveys included the entire littoral zone $(-3,370 \mathrm{~m}$ of shoreline) and were made from a slow-moving kayak. Eight surveys were completed prior to the lowest water levels of 2007 (5 surveys in 2005, 2 in 2006, and 1 in early 2007). Seven surveys were done during the low water in 2007. The 25 post-drought surveys included 5 in 2008, 4 in 2009, 2 in 2010, 4 in 2011, 6 in 2012, and 4 in 2013. Two whole-lakeshore boat electrofishing surveys (Smith-Root GPP 9.0; Smith-Root, Vancouver, WA) were done during daylight hours in 2013 (July and August) to survey for African jewelfish and to attempt to collect additional fish species to those observed during visual sampling if present.

\section{Predation experiments}

Two tank experiments were done to test the hypothesis that predation may have played a key role in the collapse of African jewelfish abundance in Lake St. Clair. The first experiment tested for differences in survival of African jewelfish under predation threat from largemouth bass across a range of habitat complexity (largemouth bass challenge). The other experiment tested the effects of eastern mosquitofish on African jewelfish (eastern mosquitofish challenge). Largemouth bass and eastern mosquitofish are common native species in Florida, are thought to resist invasion by non-native fishes (Hill et al. 2011, Thompson et al. 2012), and present non-native fishes with differing challenges (Hill et al. 2011). Largemouth bass is a large-bodied (up to $>500 \mathrm{~mm} \mathrm{TL}$ ) gape-limited predator that often restricts the use of open waters by small-bodied fishes 
(Werner et al. 1983, Hambright et al. 1991, Hill et al. 2006). Eastern mosquitofish is small-bodied ( $-60 \mathrm{~mm}$ TL) predator and aggressive competitor (Meffe 1985, Hill et al. 2011) that influences use of structured habitats by small fishes (Thompson et al. 2012). Fish were collected from research ponds at the UF/IFAS Tropical Aquaculture Laboratory, Ruskin, Florida. Fish were used only once during the experiments.

The largemouth bass challenge had three treatments that varied by the strength of the predation refuge provided by habitat-(1) strong which simulated conditions prior to the low-water period when thick stands of submersed and emergent aquatic macrophytes were present, (2) weak which simulated a transitional period when most complex habitat was stranded but some vegetation remained underwater, and (3) none which simulated low-water conditions where virtually no complex habitat remained inundated. The strong refuge treatment had artificial vegetation $\left(645 \mathrm{stems} / \mathrm{m}^{2}\right)$ consisting of black plastic strips tied to a plastic lighting grate that covered $50 \%$ of the tank bottom (Savino and Stein 1982) and a vertical barrier consisting of netting (3.8$\mathrm{cm}$ mesh) fitted $8 \mathrm{~cm}$ outside the artificial vegetation. Largemouth bass were excluded from the vegetation by the barrier but African jewelfish could freely swim through the barrier into open water. The barrier functioned to restrict the movement of largemouth bass and their access to prey, mimicking thick vegetation (Engel 1987). The weak refuge treatment had the artificial vegetation but lacked the barrier. The remaining treatment had no habitat refuge for the African jewelfish.

The experiment was done in concrete tanks $(221 \mathrm{~cm} \times 79 \mathrm{~cm} \times 58 \mathrm{~cm}$; water depth $30 \mathrm{~cm}$ ) on a re-circulating system in a greenhouse at the UF/IFAS Tropical Aquaculture Laboratory, Ruskin, Florida. Water parameters were: dissolved oxygen $=>8 \mathrm{ppm}$, temperature $=24-30{ }^{\circ} \mathrm{C}, \mathrm{pH}=7.9-8.1$, total ammonia nitrogen $<1.0 \mathrm{ppm}$, nitrite $<$ $0.02 \mathrm{ppm}$, total alkalinity $=188 \mathrm{ppm}$, and total hardness $=342 \mathrm{ppm}$. Four replicates of each treatment were randomly assigned to tanks in the system. Ten African jewelfish (mean TL $\pm S D=64 \pm 12 \mathrm{~mm}$ ) were stocked into each tank and a single largemouth bass ( $205 \pm 21 \mathrm{~mm} \mathrm{TL})$ was stocked 3 days later. The African jewelfish were morphologically vulnerable to the largemouth bass based on prey body depth and predator gape size (Hill et al. 2006). African jewelfish were fed a commercial feed at a rate of 5\% body weight per day to simulate food resources in natural water bodies (Thompson et al. 2012). Experiments lasted 4 days after which all African jewelfish were removed and counted. Additional tanks $(n=4$ without artificial vegetation and $n=4$ with artificial vegetation; duration of 4 days each) stocked only with African jewelfish were run prior to and following the experiment to determine if there was a loss rate of the prey in the absence of predators; no African jewelfish were lost or died during these trials. Differences in survival were tested using analysis of variance (ANOVA) on arcsine-square root transformed data using SAS v9.3 (SAS Institute, Cary, NC, USA). Tukey's HSD multiple comparison procedure was used to determine which treatments differed following a statistically significant ANOVA.

The eastern mosquitofish challenge was done in oval polyethylene tanks with an area of about $1.2 \mathrm{~m}^{2}$ at the base and $1.4 \mathrm{~m}^{2}$ at the water surface (water depth $25 \mathrm{~cm}$ ). Tanks were on a flow-through system receiving aerated well water. Water parameters 
were: dissolved oxygen $=7-8 \mathrm{ppm}$, temperature $=26-28^{\circ} \mathrm{C}, \mathrm{pH}=8.0$, unionized ammonia nitrogen undetectable, nitrite $<0.05 \mathrm{ppm}$, total alkalinity $=170 \mathrm{ppm}$, and total hardness $=459 \mathrm{ppm}$. Artificial vegetation $\left(216 \mathrm{stems} / \mathrm{m}^{2}\right)$ was centrally located to cover $49 \%$ of the tank bottom (Savino and Stein 1982; Thompson et al. 2012). Four replicates of two treatments were done-(1) 50 eastern mosquitofish $(30 \pm 6 \mathrm{~mm} \mathrm{TL})$ stocked on day 1 or (2) mosquitofish-free controls. Five African jewelfish $(57 \pm 6 \mathrm{~mm}$ $\mathrm{TL})$ were stocked into each tank on day 1 . These densities were within the range of densities observed in the lake prior to the low water period (see also Thompson et al. 2012). Fish were fed a commercial feed at a rate of $5 \%$ body weight per day to simulate food resources in natural water bodies (Thompson et al. 2012). Fish were removed and counted after 10 days. All surviving African jewelfish were scored for caudal fin damage, a common sign of eastern mosquitofish attack (Meffe 1985, Hill et al. 2011).

\section{Results}

\section{Field observations}

Habitat complexity within the littoral zone was high before and after the low water period and was low during the drought (Fig. 1). Decline in complexity was evident near the end of 2006 with the main low water period of 2007 having values of 0 for $60 \%$ of samples. Complexity increased during 2008 (Fig. 1). Some variation occurred as higher lake levels returned due to flooding of terrestrial vegetation and re-growth of aquatic macrophytes.

African jewelfish were observed in quantitative samples each year from 2003 until the low-water period of 2007 (Fig. 1a). The mean $( \pm S D)$ number observed for 47 samples prior to spring 2007 was $17.7( \pm 7.9)$. Only 3 individuals were observed in 3 samples during the low water period. Following the drought, no African jewelfish was observed in any transect until 2012. An average of $0.7( \pm 1.0)$ African jewelfish per transect was noted in 15 samples in 2012 and $2.3( \pm 1.6)$ per transect in 16 samples in 2013. The small number of observed African jewelfish in 2003 was related to the presence of dense surface mats of Hydrocotyle; observations in other areas of the lake suggested that they were common.

Abundance of small-bodied native fishes declined substantially during the low water period but rebounded quickly following increases in water levels and habitat complexity (Fig. 1b). Eastern mosquitofish was generally abundant whenever vegetation was present but also extensively used shallow waters along the lake edge. The abundance of larger-bodied species such as largemouth bass and adult bluegill had no apparent pattern of fluctuation related to habitat complexity (Fig. 1c).

Whole lake presence/absence surveys revealed African jewelfish throughout the littoral zone prior to the drought, but none were observed post-drought until 2012. Presence of small numbers of African jewelfish was noted in the south and southeast portions of the lake in five of six surveys in 2012 and in the south, southeast, and 
(a)

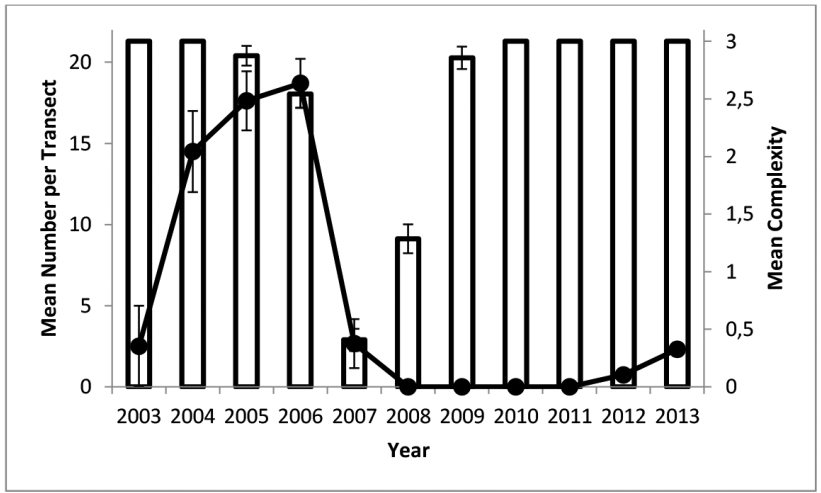

(b)

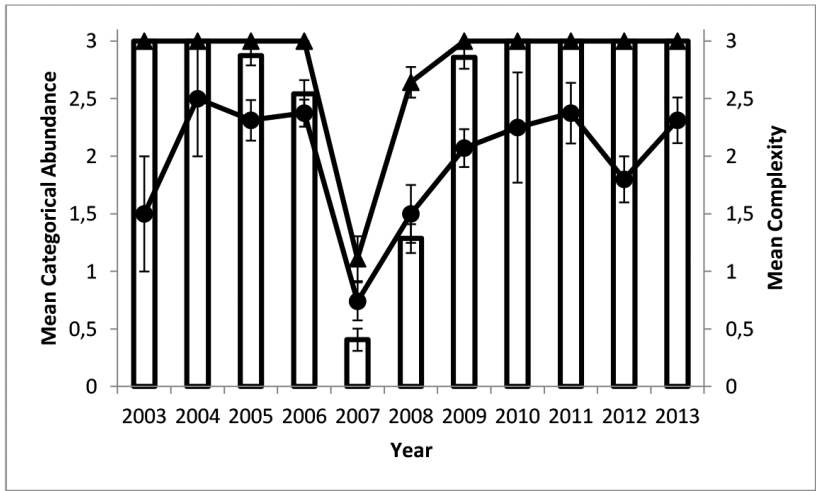

(c)

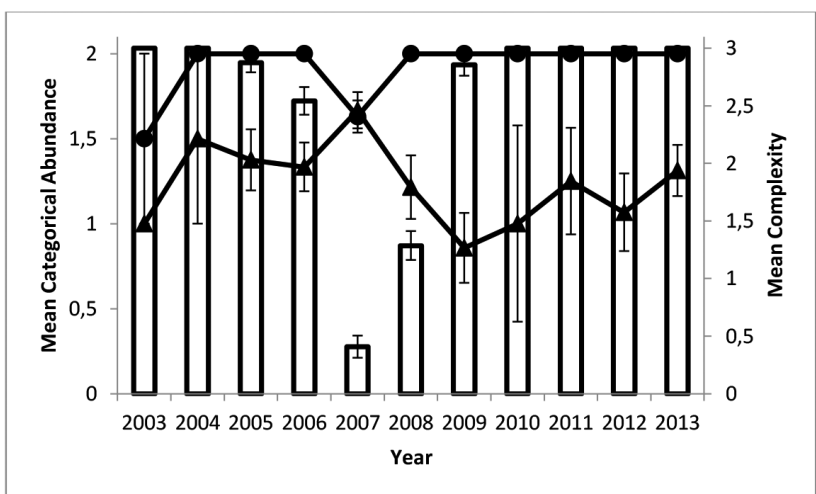

Figure I. Trends in habitat complexity and fish abundance in Lake St. Clair. Abundance $( \pm$ SE) of a African jewelfish (circles), b juvenile bluegill (circles) and eastern mosquitofish (triangles), and $\mathbf{c}$ adult bluegill (circles) and largemouth bass (triangles) in visual transects across years in Lake St. Clair, Florida. Scales for fish abundance vary by panel. Mean habitat complexity ( \pm SE; bars) across years is on the secondary y-axis ( $0=$ absent, $1=<33 \%$ coverage, $2=33-66 \%$ coverage, and $3=>66 \%$ coverage). African jewelfish abundance is number per transect. Abundance for juvenile bluegill and eastern mosquitofish is on a categorical scale ( $0=$ absent, $1=1-19,2=20-99$, and $3=100$ or more observed per transect). Abundance for adult bluegill and largemouth bass is on a categorical scale $(0=$ absent, $1=1-5$, and $2=$ 6 or more observed per transect) 
southwest portions in all surveys in 2013. No African jewelfish were noted in other sections of the lake post-drought. Native bluegill, eastern mosquitofish, and largemouth bass were noted in all sections of the lake in all surveys.

Native fishes observed during this study, in relative order of abundance, were eastern mosquitofish, bluegill, largemouth bass, channel catfish (Ictalurus punctatus Rafinesque), golden shiner (Notemigonus crysoluecas Mitchill), warmouth (Lepomis gulosus Cuvier), black crappie (Pomoxis nigromaculatus Lesueur), and golden topminnow (Fundulus chrysotus Gunther). Non-native fishes besides African jewelfish were not observed during visual sampling but walking catfish (Clarias batrachus Linnaeus; $\mathrm{n}=$ 2 ) and Asian swamp eel (Monopterus albus Zuiew; $\mathrm{n}=1$ ) were collected by boat electrofishing in 2013. Of these species, channel catfish likely exerted considerable predation pressures on small fishes during the low water period (Hill personal observations) but was uncommon in surveys. Channel catfish individuals were frequently observed near docks and along shorelines when lake residents provided feed and were common in angler catches (Hill personal observations).

\section{Predation experiments}

African jewelfish survival varied with habitat in the largemouth bass challenge and positively correlated with habitat complexity $\left(F_{2,11}=27.93, P=0.0001\right.$; Fig. 2$)$. Mean survival in the strong habitat refuge treatment was 1.6 times higher than in the weak refuge treatment and over 7 times higher than in the treatment lacking a habitat refuge from predation. African jewelfish survival was $100 \%$ in all tanks in the eastern mosquitofish challenge. No caudal fin damage was observed for any African jewelfish.

\section{Discussion}

The collapse of African jewelfish abundance in Lake St. Clair was dramatic and rapid. African jewelfish were common in visual surveys for 4 years but were not observed for nearly 5 years following a major low-water event where virtually all structurally complex habitat was stranded above the water level. Abundance of native small-bodied fishes showed a similar though less dramatic pattern of decline as habitat complexity decreased. However, these species rapidly rebounded following a return of complex habitat. Larger-bodied natives showed little pattern relative to changing habitat complexity. The main predatory species in open waters, largemouth bass, was common throughout the study period. Predation experiments showed that the vulnerability of African jewelfish to a large-bodied, open-water predator increased with decreasing habitat complexity. Conversely, African jewelfish survival was not affected by a smallbodied native species within complex habitats. These results support the hypothesis that habitat-related changes in predation dynamics contributed to a marked decline in African jewelfish abundance in Lake St. Clair. 


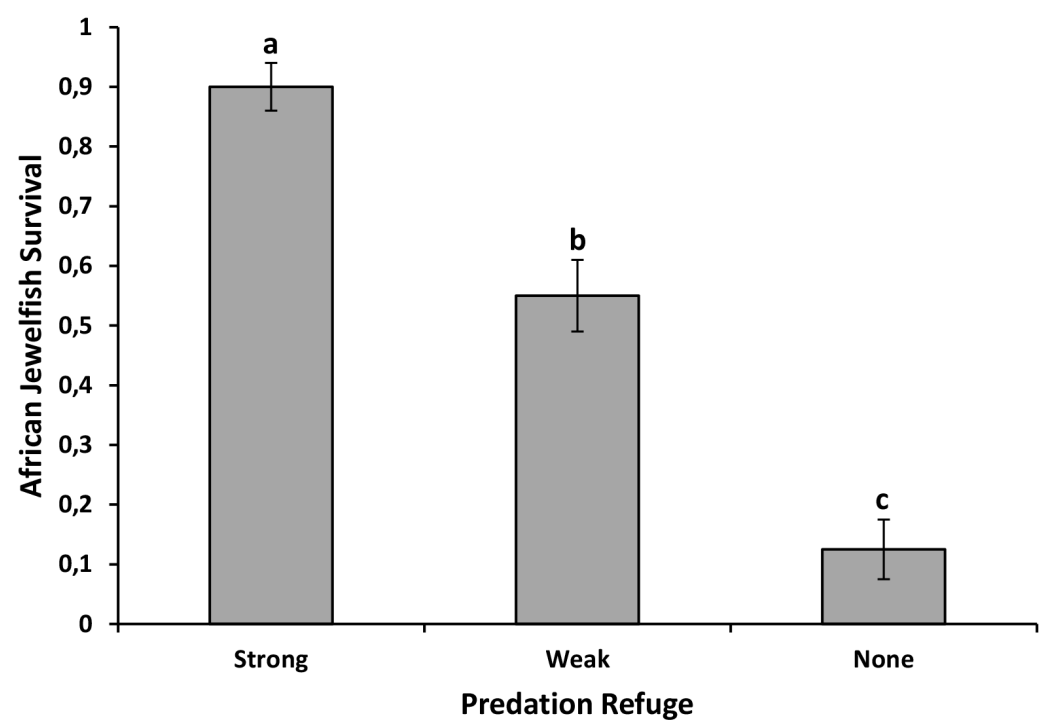

Figure 2. African jewelfish survival across habitat types in an experiment with largemouth bass as a predator. Mean survival $( \pm S E)$ across strong, weak, or no predation refuge. Different letters denote statistically different treatment means $(P<0.05)$.

Prey persist in the environment because some portion of the population is invulnerable to predation at any one time (Matter and Mannan 2005). Morphological vulnerability of African jewelfish (Hill et al. 2006) suggests that this species must exploit behavioral or habitat refuges to escape predation. Structurally complex habitat limits access of large-bodied predators to smaller prey (Engle 1987), reduces the efficiency of predators (Savino and Stein 1982), and decreases the proportion of fish in predator's diets (Bettolli et al. 1992). African jewelfish is highly associated with structurallycomplex habitats such as aquatic macrophytes (Shafland 1996, Hill personal observations) and has declined dramatically in some south Florida canals concurrent with the near elimination of aquatic vegetation by water managers (Shafland et al. 2008, Hill unpublished data). African jewelfish in experimental tanks largely remained within the artificial vegetation and behind the barrier when these habitat features were available, an effective strategy to reduce vulnerability and increase survival. African jewelfish without effective cover were highly vulnerable to predation, suggesting the need for refuge habitat for persistence in the presence of open water predators. Normal water levels in Lake St. Clair provide considerable refuge habitat. Low water levels removed virtually all structurally complex habitat and exposed African jewelfish to open water predators.

Structurally complex habitat may not be sufficient refuge from predators for some fish species (MacRae and Jackson 2001). Research suggests that eastern mosquitofish harass and consume small-bodied non-native fishes and reduce refuge quality of shallows and structurally complex habitat via agonistic interactions (Hill et al. 2011, 
Thompson et al. 2012). Eastern mosquitofish had no effect on adult African jewelfish survival in experimental tanks and no observations suggest that eastern mosquitofish attack or displace African jewelfish from refuge habitat. These results imply little influence of eastern mosquitofish on biotic resistance against this non-native species, perhaps contributing to the nearly unique success among small-bodied fishes of African jewelfish as a widespread, established invader in Florida (see Thompson et al. 2012). Conversely, eastern mosquitofish and the highly similar western mosquitofish (Gambusia affinis Baird \& Girard) frequently reduce the survival of larval or juvenile fishes by predation (Meffe 1985, Taylor et al. 2001, Thompson et al. 2012); eastern mosquitofish effects on early life stages of African jewelfish require additional investigation.

Unlike African jewelfish, small native fishes rapidly rebounded from their reduced abundance. Eastern mosquitofish were able to refuge from larger fishes during the low water period by exploiting the shallow lake margins (see DeVries 1990, Paterson and Whitfield 2000). This live-bearing fish has high reproductive output with sexual maturity at 1-2 months, gestation periods of 2-3 weeks, and brood sizes averaging up to 100 offspring (Pyke 2005). Reproduction is nearly year-round in Florida (Hill personal observations). Juvenile bluegills never disappeared entirely and were replenished by multiple yearly breeding cycles accomplished by relatively large, and therefore less vulnerable, adults which are capable of using open water habitats (Paukert and Willis 2002). Despite being robust and generally successful as an invader (Langston et al. 2010), the small and brightly colored adult African jewelfish were vulnerable to predators with the loss of refuge habitat and despite frequent spawning bouts and parental care their life history strategy apparently proved inadequate to maintain their abundance.

The results of the present study do not exclude other hypotheses that might partly explain the observed population collapse. Nevertheless, other factors potentially reducing African jewelfish abundance were not evident. Population size was fairly large and the species was distributed throughout the entire littoral zone where vegetation was present, suggesting that Allee effects and stochasticity of small population demographics were not important (Dennis 2002). Cold winter temperatures may eliminate this species from small, shallow aquaculture ponds in this region, though populations in nearby lakes of smaller surface area and lesser depth than Lake St. Clair persisted through a major cold event of the winter of 2009-2010 (Hill personal observations; see also Schofield et al. 2010). Moreover, African jewelfish were present in surveys done in early 2007 (late winter) prior to the extreme low-water conditions. Besides low water levels, no unusual water conditions were observed nor were fish kills of African jewelfish or any other species. African jewelfish is hardy and adaptable to a wide range of environmental conditions (Schofield et al. 2007, Langston et al. 2010) and occurs commonly in waters receiving road, residential, and agricultural runoff (Hill personal observations). Some unobserved disease might have affected the population, but, as recommended by Simberloff and Gibbons (2004), an unidentified pathogen is only an "explanation of last resort."

Recovery of collapsed populations of non-natives is of as much interest as the collapse itself. Unfortunately, the origin of the African jewelfish observed in 2012 
is unknown. A slow increase in abundance and spatial range of African jewelfish is evident since this time (present study, Hill personal observations). Re-colonization of Lake St. Clair from regional water bodies is unlikely because there are no direct water connections except for the overflow structure and pipe discharging into a small tributary stream. Access via this route is highly unlikely due to intermittent flow in both the discharge pipe and receiving stream, the large gap between lake levels and the overflow structure during the time period (usually $60-90 \mathrm{~cm}$ or more), and the large elevation difference between the structure and the outlet. Release by humans is a probable cause of re-establishment in the lake, especially at the public access area (e.g., Copp et al. 2005). Fishing for largemouth bass is common on the lake and live African jewelfish collected from other regional waters have been used as bait (illegally) in Lake St. Clair during the period between low water and their subsequent detection in surveys (2007-2012; Hill personal observations). It is also possible that some African jewelfish survived the low-water period and persisted at such low abundance that they were missed in surveys until 2012. Periodic monitoring would determine if African jewelfish returns to its former abundance or remains a minor component of the lake's fish fauna. Similarly, surveys of regional waters with historic records would yield insights into the commonality of collapse in African jewelfish populations.

Management options may be few once non-native fishes establish (Kolar et al. 2010). For situations where non-natives are confined to small, closed water bodies, use of rotenone or other chemical treatments may be effective (e.g., Hill and Cichra 2005). Removals using active or passive capture techniques are seldom effective at eradication (Kolar et al. 2010, but see Hill and Sowards 2015). Predatory fishes are stocked in some situations to control non-native fishes (e.g., Shafland 1995), though eradication is not typical. Partial de-watering to strand structurally-complex refuge habitat or removal of aquatic vegetation could increase the effectiveness of resident or stocked predatory fishes in controlling or eliminating susceptible non-natives. For example, habitat simplification has been shown experimentally to increase the predatory effects of largemouth bass and other common predators (Savino and Stein 1982, Alexander et al. 2015). Elimination of aquatic vegetation may additionally remove preferred habitat and thus reduce abundance of vegetation-dependent species (e.g., Schofield and Nico 2007). Vegetation removal is a typical preliminary step to chemical application (Finlayson et al. 2010) and might be a sufficient action if the risk of the spread of the species is not unacceptable relative to the cost, collateral kill, and public relations challenge that may accompany fish toxicant application (Britton et al. 2011). The potential for effective control or eradication by predators also should be considered for water bodies where fish toxicant application is impractical. Use of manipulation of habitat complexity as a control measure for non-native fishes, just as with other control methods, would require a plan to monitor the water body for nonnative persistence, taking into account the characteristics of the water body and the non-native species, and to reduce or eliminate re-introduction of the non-native from local dispersal or human activities. 
Simberloff and Gibbons (2004) found little directed research investigating collapse of non-native species populations and concluded that this phenomenon is of little importance to invasion biology. However, since 2004 additional examples of population collapse have been observed in non-native taxa as diverse as ants (Cooling et al. 2012), crayfish (Sandstrom et al. 2014), and mammals (Sheehy and Lawton 2014). Few additional fish examples have been published but spontaneous collapse for unknown reasons has been noted for the widespread, invasive topmouth gudgeon (Pseudorasbora parva Temminck and Schlegel) in Europe (Copp et al. 2007). Predation by native species is seldom thought to be the cause of these newer examples (but see Sheehy and Lawton 2014). Boom-and-bust cycles and spontaneous population collapse for non-native fishes in Florida are mentioned in the literature but accounts are largely anecdotal (but see Harrison et al. 2013 and Boucek and Rehage 2014 for cold effects). Although cichlids are among the most numerous and successful established non-native fishes in Florida (Shafland et al. 2008), population abundance and range of several species have fluctuated considerably and some species have disappeared from the state, generally with no known cause (Shafland 1996, Shafland et al. 2008, USGS 2015). One of the most prevalent mechanisms to explain boom-and-bust cycles of native fishes is the effect of the interaction of environmental factors and life history traits on annual recruitment (e.g., Lobon-Cervia 2009, Matthews and MarshMatthews 2011). This is likely a rich area of future research investigating population fluctuations of Florida non-natives (e.g., the influence of major cold events; Schofield et al. 2010, Harrison et al. 2013, Boucek and Rehage 2014). As suggested by the present study, biotic resistance through predation likewise may prove an important mechanism. If population collapse is indeed as common, yet understudied, as suggested by a casual review of the literature for Florida, much additional research is warranted. A parallel can be drawn between population collapse and failed invasions, a more widely acknowledged yet similarly understudied phenomenon in the literature (Zenni and Nunez 2013). Greater attention to these occurrences can give insight into processes linked to invasion success, thus providing a more complete picture of the importance of population collapse and its potential use in risk analysis and non-native species management.

\section{Acknowledgments}

I thank Susan Hill and Katelyn Lawson, Emily Haug, and Jared Ritch (Tropical Aquaculture Laboratory, University of Florida) for assistance, Kelly Gestring and Bill Pouder (Florida Fish and Wildlife Conservation Commission) for information, Joel Trexler (Florida International University) and Pam Schofield (U.S. Geological Survey) for constructive comments, and the University of Florida's Institute of Food and Agricultural Sciences and the Florida Fish and Wildlife Conservation Commission for funding. All applicable institutional guidelines for the care and use of animals were followed: UF IACUC \#201004511. 


\section{References}

Alexander ME, Kaiser H, Weyl OLF, Dick JTA (2015) Habitat simplification increases the impact of a freshwater invasive fish. Environmental Biology of Fishes 98: 477-486. doi: $10.1007 / \mathrm{s} 10641-014-0278-\mathrm{z}$

Baltz DM, Moyle PB (1993) Invasion resistance to introduced species by a native assemblage of California stream fishes. Ecological Applications 3: 246-255. doi: 10.2307/1941827

Barrientos CA, Allen MS (2008) Fish abundance and community composition in native and non-native plants following hydrilla colonization at Lake Izabal, Guatemala. Fisheries Management and Ecology 15: 99-106. doi: 10.1111/j.1365-2400.2007.00588.x

Bettoli PW, Maceina MJ, Noble RL, Betsill RK (1992) Piscivory in largemouth bass as a function of vegetation abundnace. North American Journal of Fisheries Management 12: 509-516. doi: 10.1577/1548-8675(1992)012<0509:PILBAA>2.3.CO;2

Bettoli PW, Maceina MJ, Noble RL, Betsill RK (1993) Response of a reservoir fish community to aquatic vegetation removal. North American Journal of Fisheries Management 13: 101-124. doi: 10.1577/1548-8675(1993)013<0110:ROARFC>2.3.CO;2

Boucek RE, Rehage JS (2014) Climate extremes drive changes in functional community structure. Global Change Biology 20: 1821-1831. doi: 10.1111/gcb.12574

Britton JR, Gozlan RE, Copp GH (2011) Managing non-native fish in the environment. Fish and Fisheries 12: 256-274. doi: 10.1111/j.1467-2979.2010.00390.x

Byers JE (2002) Physical habitat attribute mediates biotic resistance to non-indigenous species invasion. Oecologia 130: 146-156. doi: 10.1007/s004420100777

Call ME, Sechler DR, Canter S, Stevens PW (2013) Freshwater fish communities and habitat use in the Peace River, Florida. Florida Scientist 76: 150-165.

Chick JH, McIvor CC (1997) Habitat selection by three littoral zone fishes: effects of predation pressure, plant density and macrophyte type. Ecology of Freshwater Fish 6: 27-35. doi: 10.1111/j.1600-0633.1997.tb00139.x

Colle DE, Shireman JV (1994) Use of grass carp in two Florida lakes, 1975-1994. In: Proceedings of the Grass Carp Symposium. U.S. Army Corps of Engineers, Vicksburg, Mississippi, 111-120.

Cooling M, Hartley S, Sim DA, Lester PJ (2012) The widespread collapse of an invasive species: Argentine ants (Linepithema humile) in New Zealand. Biology Letters 8: 430-433. doi: $10.1098 / \mathrm{rsbl} .2011 .1014$

Copp GH, Wesley KJ, Verreycken H, Russell IC (2007) When an 'invasive' fish species fails to invade! Example of the topmouth gudgeon Pseudorasbora parva. Aquatic Invasions 2: 107-112. doi: 10.3391/ai.2007.2.2.4

Copp GH, Wesley KJ, Vilizzi L (2005) Pathways of ornamental and aquarium fish introductions into urban ponds of Epping Forest (London, England): the human vector. Journal of Applied Ichthyology 21: 263-274. doi: 10.1111/j.1439-0426.2005.00673.x

Courtenay WR Jr, Sahlman HF, Miley WW II, Herrema DJ (1974) Exotic fishes in fresh and brackish waters of Florida. Biological Conservation 6: 292-302. doi: 10.1016/00063207(74)90008-1

Dennis B (2002) Allee effects in stochastic populations. Oikos 96:389-401. doi: 10.1034/j.16000706.2002.960301.x 
DeVries DR (1990) Habitat use by bluegill in laboratory pools: where is the refuge when macrophytes are sparse and alternative prey are present? Environmental Biology of Fishes 29: 27-34. doi: 10.1007/BF00000565

Diaz-Ferguson E, Herod J, Galvez J, Moyer G (2014) Development of molecular markers for eDNA detection of the invasive African jewelfish (Hemichromis letourneuxi): a new tool for monitoring aquatic invasive species in National Wildlife Refuges. Management of Biological Invasions 5: 121-131. doi: 10.3391/mbi.2014.5.2.05

Engel S (1987) The impact of submerged macrophytes on largemouth bass and bluegills. Lake and Reservoir Management 3: 227-234. doi: 10.1080/07438148709354778

Finlayson B, Schnick R, Skaar D, Anderson J, Demong L, Duffield D, Horton W, Steinkjer J (2010) Planning and standard operating procedures for the use of rotenone in fish management. American Fisheries Society, Bethesda, Maryland.

Fury JR, Morello FA (1994) The contribution of an exotic fish, the oscar, to the sport fishery of the Everglades Water Conservation Areas. Proceedings of the Annual Conference of the Southeastern Association of Fish and Wildlife Agencies 48: 474-481

Gotceitas V, Colgan P (1989) Predator foraging success and habitat complexity: quantitative test of the threshold hypothesis. Oecologia 80: 158-166. doi: 10.1007/BF00380145

Hambright KD, Drenner RW, McComas SR, Hairston NG Jr (1991) Gape-limited piscivores, planktivore size refuges, and the trophic cascade hypothesis. Archiv fur Hydrobiologie 121: 389-404.

Harrison E, Lorenz JJ, Trexler JC (2013) Per capita effects of non-native Mayan cichlids (Cichlasoma urophthalmus; Gunther) on native fish in the estuarine southern Everglades. Copeia 2013: 80-96. doi: 10.1643/CE-11-182

Harvey BC, White JL, Nakamoto RJ (2004) An emergent multiple predator effect may enhance biotic resistance in a stream fish assemblage. Ecology 85: 127-133. doi: 10.1890/03-3018

Hill JE, Cichra CE (2005) Eradication of a reproducing population of convict cichlids, Cichlasoma nigrofasciatum (Cichlidae), in north-central Florida. Florida Scientist 68: 65-74.

Hill JE, Kapuscinski AR, Pavlowich T (2011) Fluorescent transgenic zebra danio more vulnerable to predators than wild-type fish. Transactions of the American Fisheries Society 140: 1001-1005. doi: 10.1080/00028487.2011.603980

Hill JE, Nico LG, Cichra CE, Gilbert CR (2006) Prey vulnerability to peacock cichlids and largemouth bass based on predator gape and prey body depth. Proceedings of the Annual Conference of the Southeastern Association of Fish and Wildlife Agencies 58(2004): 47-56.

Hill JE, Sowards J (2015) Successful eradication of the non-native loricariid catfish Pterygoplichthys disjunctivus from the Rainbow River, Florida. Management of Biological Invasions 6: 311-317. doi: 10.3391/mbi.2015.6.3.11

Kline JL, Loftus WF, Kotun K, Trexler JC, Rehage JS, Lorenz JJ, Robinson M (2013) Recent fish introductions into Everglades National Park: an unforeseen consequence of water management? Wetlands 34(Supplement 1): S175-S187. doi: 10.1007/s13157-012-0362-0

Kolar CS, Courtenay WR Jr., Nico LG (2010) Managing undesired and invading fishes. In: Hubert WA, Quist MS (Eds) Inland fisheries management in North America, $3^{\text {rd }}$ ed. American Fisheries Society, Bethesda, Maryland, 213-259. doi: 10.1643/CP-09-069 
Langston JN, Schofield PJ, Hill JE, Loftus WF (2010) Salinity tolerance of the African jewelfish Hemichromis letourneuxi, a non-native cichlid in south Florida (USA). Copeia 2010: 475-480.

Lobon-Cervia J (2009) Why, when and how do fish populations decline, collapse and recover? The example of brown trout (Salmo trutta) in Rio Chaballos (northwestern Spain). Freshwater Biology 54: 1149-1162. doi: 10.1111/j.1365-2427.2008.02159.x

Loftus WF, Kushlan JA (1987) Freshwater fishes of southern Florida. Bulletin of the Florida State Museum, Biological Science 31: 147-344.

MacRae PSD, Jackson DA (2001) The influence of smallmouth bass (Micropterus dolomieu) predation and habitat complexity on the structure of littoral zone fish assemblages. Canadian Journal of Fisheries and Aquatic Sciences 58: 342-351. doi: 10.1139/f00-247

Matter WJ, Mannan RW (2005) How do prey persist? Journal of Wildlife Management 69: 1315-1320. doi: 10.2193/0022-541X(2005)69[1315:HDPP]2.0.CO;2

Matthews WJ, Marsh-Matthews E (2011) An invasive fish species within its native range: community effects and population dynamics of Gambusia affinis in the central United States. Freshwater Biology 56: 2609-2619. doi: 10.1111/j.1365-2427.2011.02691.x

Meffe GK (1985) Predation and species replacement in American southwestern fishes: a case study. Southwest Naturalist 30: 173-187. doi: 10.2307/3670732

Mittelbach GG (1981) Foraging efficiency and body size: a study of optimal diet and habitat use by bluegills. Ecology 62: 1370-1386. doi: 10.2307/1937300

Moyer GR, Diaz-Ferguson E, Hill JE, Shea C (2014) Assessing environmental DNA detection in controlled lentic systems. PLoS ONE 9(7): e103767. doi: 10.1371/journal. pone. 0103767

Paterson AW, Whitfield AK (2000) Do shallow-water habitats function as refugia for juvenile fishes? Estuarine, Coastal and Shelf Science 51: 359-364. doi: 10.1006/ ecss. 2000.0640

Paukert CP, Willis DW (2002) Seasonal and diel habitat selection by bluegills in a shallow natural lake. Transactions of the American Fisheries Society 131: 1131-1139. doi: 10.1577/1548-8659(2002)131<1131:SADHSB > 2.0.CO;2

Pyke GH (2005) A review of the biology of Gambusia affinis and G. holbrooki. Reviews in Fish Biology and Fisheries 15: 339-365. doi: 10.1007/s11160-006-6394-x

Rehage JS, Liston SE, Dunker KJ, Loftus WF (2014) Fish community responses to the combined effects of decreased hydroperiod and nonnative fish invasions in a karst wetland: are Everglades solution holes sinks for native fishes? Wetlands 34(Suppl 1): S159-S173. doi: 10.1007/s13157-012-0361-1

Rivas LR (1965) Florida fresh water fishes and conservation. Quarterly Journal of the Florida Academy of Science 28: 255-258.

Sandstrom A, Andersson M, Asp A, Bohman P, Edsman L, Engdahl F, Nystrom P, Stenberg M, Hertonsson P, Vralstad T, Graneli W (2014) Population collapses in introduced nonindigenous crayfish. Biological Invasions. doi: 10.1007/s10530-014-0641-1

Sass GG, Kitchell JK, Carpenter SR, Hrabik TR, Marburg AE, Turner MG (2006) Fish community and food web responses to a whole-lake removal of coarse woody habitat. Fisheries 31: 321-330. doi: 10.1577/1548-8446(2006)31[321:FCAFWR]2.0.CO;2 
Savino JF, Stein RA (1982) Predator-prey interaction between largemouth bass and bluegills as influenced by simulated, submersed vegetation. Transactions of the American Fisheries Society 111: 255-266. doi: 10.1577/1548-8659(1982)111<255:PIBLBA>2.0.CO;2

Schofield PJ, Loftus WF, Brown ME (2007) Hypoxia tolerance of two centrarchid sunfishes and an introduced cichlid from karstic Everglades wetlands of southern Florida, USA. Journal of Fish Biology 71(Suppl D): 87-99. doi: 10.1111/j.1095-8649.2007.01686.x

Schofield PJ, Loftus WF, Kobza RM, Cook MI, Slone DH (2010) Tolerance of nonindigenous cichlid fishes (Cichlasoma urophthalmus, Hemichromis letourneuxi) to low temperature: laboratory and field experiments in south Florida. Biological Invasions 12: 2441-2457. doi: $10.1007 /$ s10530-009-9654-6

Schofield PJ, Nico LG (2007) Toxicity of 5\% rotenone to nonindigenous Asian swamp eels. North American Journal of Fisheries Management 27: 453-459. doi: 10.1577/M05-206.1 Schofield PJ, Slone DH, Gregoire DR, Loftus WF (2014) Effects of a non-native cichlid fish (African jewelfish, Hemichromis letourneuxi Sauvage 1880) on a simulated Everglades aquatic community. Hydrobiologia 722: 171-182. doi: 10.1007/s10750-013-1697-0

Shafland PL (1995) Introduction and establishment of a successful butterfly peacock bass fishery in southeast Florida canals. American Fisheries Society Symposium 15: 443-451.

Shafland PL (1996) Exotic fishes of Florida-1994. Reviews in Fisheries Science 4: 101-122. doi: 10.1080/10641269609388581

Shafland PL, Gestring KB, Stanford MS (2008) Florida's exotic freshwater fishes_-2007. Florida Scientist 71: 220-245.

Sheehy E, Lawton C (2014) Population crash in an invasive species follow recovery of a native predator: the case of the American grey squirrel and the European pine martin in Ireland. Biodiversity Conservation. doi: 10.1007/s10531-014-0632-7

Simberloff D, Gibbons L (2004) Now you see them, now you don't!- population crashes of established introduced species. Biological Invasions 6: 161-172. doi: 10.1023/B:BI NV.0000022133.49752.46

Snodgrass JW (1991) Winter kills of Tilapia melanotheron in coastal southeast Florida, 1989. Florida Scientist 54: 85-86.

Taylor RC, Trexler JC, Loftus WF (2001) Separating the effects of intra- and interspecific agestructured interactions in an experimental fish assemblage. Oecologia 127: 143-152. doi: $10.1007 /$ s004420000575

Thompson KA, Hill JE, Nico LG (2012) Eastern mosquitofish resists invasion by nonindigenous poeciliids through agonistic behaviors. Biological Invasions 14: 1515-1529. doi: 10.1007/s10530-012-0176-2

Trexler JC, Loftus WF, Jordan F, Lorenz JJ, Chick JH, Kobza RM (2000) Empirical assessment of fish introductions in a subtropical wetland: an evaluation of contrasting views. Biological Invasions 2: 265-277. doi: 10.1023/A:1011488118444

USGS (2015) Nonindigenous Aquatic Species Database, U.S. Geological Survey, Gainesville, Florida. http://nas.er.usgs.gov [accessed 15 July 2015]

Ware FJ, Gasaway RD (1976) Effects of grass carp on native fish populations in two Florida lakes. Proceedings of the Southeastern Association of Game and Fish Commissioners 13: $324-335$. 
Werner EE, Gilliam JF, Hall DJ, Mittelbach GG (1983) An experimental test of the effects of predation risk on habitat use in fish. Ecology 64: 1540-1548. doi: 10.2307/1937508

Werner EE, Hall DJ (1988) Ontogenetic habitat shifts in bluegill: the foraging rate-predation risk trade-off. Ecology 69: 1352-1366. doi: 10.2307/1941633

Werner EE, Hall DJ, Werner MD (1978) Littoral zone fish communities of two Florida lakes and a comparison with Michigan lakes. Environmental Biology of Fishes 3: 163-172. doi: 10.1007/BF00691940

Zenni RD, Nunez MA (2013) The elephant in the room: the role of failed invasions in understanding invasion biology. Oikos 122: 801-815. doi: 10.1111/j.1600-0706.2012.00254.x 